\title{
10 health stories that mattered: Sept. 13-19
}

- Canadian health officials are on alert for enterovirus D68, a rare virus that can lead to severe respiratory illness, as more children enter hospitals with breathing difficulties in provinces across Canada, including Alberta, Ontario and British Columbia. The virus continues to spread in the United States, where more than 100 cases have been confirmed since mid-August.

- The participation of children in clinical trials, which has historically been frowned upon in Canada, is necessary to develop safe and effective pediatric medicines, according to a report by the Council of Canadian Academies. The report, commissioned by Health Canada, notes that children respond differently to medication than adults, yet millions of Canadian children annually use prescription drugs that have not been proven safe or effective for their age group.

- According to Statistics Canada, the majority of Canadians (76.9\%) enjoy "flourishing" mental health, many $(21.6 \%)$ fall into the "moderate" category and only a small percentage $(1.5 \%)$ would be considered "languishing" in this area, based on data from 2012 and definitions from the Mental Health Continuum-Short Form. Compared to previous studies and many other populations, the mental health of Canadians appears to be flourishing at a high rate, though differences in survey methodologies may account for some variations.
- Based on records from the US Food and Drug Administration (FDA), at least 18 Canadian medical researchers failed to report adverse events from their clinical trials, according to the Toronto Star. "Objectionable conditions" were found in more than $60 \%$ of the study sites visited by the FDA since 1981, reports the Star, and several researchers were "repeat offenders."

- The Canadian military is under pressure to improve mental health services for its soldiers, who died in greater numbers from suicide than combat in Afghanistan. Between 2004 and Mar. 31, 2014, there were 160 suicides among military personnel, compared to 138 deaths in combat.

- Heath Canada has asked IPCA Laboratories, a pharmaceutical firm in India, to stop sending products to Canada based on a report by the US Food and Drug Administration that indicates the company falsified and manipulated data. Though there are no apparent health risks to consumers, and therefore no imminent recall, Health Canada has asked Canadian companies to temporarily quarantine products with active pharmaceutical ingredients imported from IPCA Laboratories.

- More than \$2.5 million worth of personal protective equipment is headed to West Africa, courtesy of the Canadian government, to assist in the fight against Ebola. Affected countries are running low on safety gear, such as respirator masks and face shields, prompting the World Health Organization to appeal to member states for donations.

- Grade 5 boys in Alberta can now be immunized against the human papillomavirus (HPV), joining the vaccine program offered to girls of the same age since 2008. The province will also offer a vaccine catchup program to boys in Grade 9, and aims to vaccinate 30000 boys this year.

- According to a union representing registered nurses, the safety of patients in Saskatchewan may be at risk if the government approves bylaw changes to expand the roles of licensed practical nurses, who receive less training. But the provincial body representing licensed practical nurses counters that the proposed changes are meant to clarify the roles they already play and the union's objections amount to "fear-mongering" and "hysteria."

- Negotiations over salary increases remain tense in Quebec between medical specialists and Health Minister Gaétan Barrette, who is attempting to rein in health care costs to help the province balance its budget. The Fédération des médecins spécialistes du Québec has accused the minister of negotiating "in bad faith," and Barrette suggested the federation has made "veiled threats" about using pressure tactics to get its way. Roger Collier, CMAJ

CMAJ 2014. DOI:10.1503/cmaj.109-4907 